\title{
Impact of varying debris cover thickness on ablation: a case study for Koxkar Glacier in the Tien Shan
}

\author{
M. Juen ${ }^{1}$, C. Mayer ${ }^{1}$, A. Lambrecht ${ }^{1}$, H. Han ${ }^{2}$, and S. Liu ${ }^{2}$ \\ ${ }^{1}$ Commission for Geodesy and Glaciology, Bavarian Academy of Sciences, Munich, Germany \\ ${ }^{2}$ State Key Laboratory of Cryospheric Sciences, Cold and Arid Regions Environmental and Engineering Research Institute, \\ Chinese Academy of Sciences, Lanzhou, China
}

Correspondence to: M. Juen (martin.juen@kfg.badw.de) and C. Mayer (christoph.mayer@lrz.badw-muenchen.de)

Received: 11 September 2013 - Published in The Cryosphere Discuss.: 5 November 2013

Revised: 22 January 2014 - Accepted: 24 January 2014 - Published: 7 March 2014

\begin{abstract}
To quantify the ablation processes on a debris covered glacier, a simple distributed ablation model has been developed and applied to a selected glacier. For this purpose, a set of field measurements was carried out to collect empirical data. A morphometric analysis of the glacier surface enables us to capture statistically the areal distribution of topographic features that influence debris thickness and consequently ablation. Remote-sensing techniques, using highresolution satellite imagery, were used to extrapolate the in situ point measurements to the whole ablation area and to map and classify melt-relevant surface types. As a result, a practically applicable method is presented that allows the estimation of ablation on a debris covered glacier by combining field data and remote-sensing information. The subdebris ice ablation accounts for about $24 \%$ of the entire ice ablation, while the percentage of the moraine covered area accounts for approximately $32 \%$ of the entire glacierized area. Although the ice cliffs occupy only $1.7 \%$ of the debris covered area, the melt amount accounts for approximately $12 \%$ of the total sub-debris ablation and $2.5 \%$ of the total ablation respectively. Our study highlights the influence of debris cover on the response of the glacier terminus in a particular climate setting. Due to the fact that melt rates beyond $0.1 \mathrm{~m}$ of moraine cover are highly restricted, the shielding effect of the debris cover dominates over the temperature and elevation dependence of the ablation in the bare ice case.
\end{abstract}

\section{Introduction}

Debris covered glaciers are a prominent feature in high relief mountain ranges like the Tien Shan, the Himalayas or the Karakoram. These glaciers are characterized by the presence of supraglacial debris mantles in the ablation zones that can originate from various sources, such as thrusting of subglacial material, rockfall from mountain sides or aeolian deposition directly onto the glacier surface (Schomacker, 2008). Several studies have concentrated on the relationship between debris cover thickness and sub-debris ice melt rates since the fundamental contribution of Østrem (1959). When solar radiation is present, very thin layers of debris or small single grains absorb more heat than ice, due to their lower albedo. The transfer of this energy into the underlying ice increases ablation rates. Thicker supraglacial debris covers act as a protecting carapace, which insulates the underlying ice and significantly reduces ablation (Østrem, 1959). The response of debris covered glaciers to climate change and therefore the prediction of future water availability are the subject of current research (e.g. Scherler et al., 2011; Benn et al., 2012; Bolch et al., 2012). Several physically based models that calculate sub-debris melt rates based on meteorological variables and debris thermal properties have been developed during the recent past (Nicholson and Benn, 2006; Reid and Brock, 2010). However, these physically based models require a wide range of input data whose determination is difficult, time consuming and expensive, especially for larger areas. They are important for process studies at point locations, but the application for large glaciers or even basin-wide calculations remains difficult. To determine the 
ablation of a whole debris covered glacier, robust conceptual approaches with empirically derived functions have been proven to produce realistic results (e.g. Braun et al., 2000; Hagg et al., 2007).

Apart from the debris coverage, ice cliffs and supraglacial lakes are also important features of debris covered glaciers: they are widely recognized as spots of enhanced melting (Sakai et al., 2002, 2000). The exposed areas of steeply inclined ice are normally covered with a very thin layer of dust or sand, leading to higher absorption of shortwave radiation due to the low albedo compared to clean ice. Supraglacial lakes produce internal ablation in the conduit system that leads to a positive feedback process, accelerating the ablation rate of debris covered glaciers (Gulley and Benn, 2007; Benn et al., 2012). Following the collapse of englacial channels, new ice cliffs and ponds are created.

To quantify these melt processes on a debris covered glacier, this study applies a distributed ablation model to a selected glacier.

\section{Study area}

Field observations have been carried out on the moraine covered ablation area of Koxkar Glacier, located in the Xinjiang Uyghur Autonomous Region of northwestern China $\left(41.76^{\circ} \mathrm{N}, 80.11^{\circ}\right.$ E; Fig. 1$)$.

The glacier is situated in the Central Tien Shan, one of the largest mountain ranges in Central Asia. Melt water originating from the glaciers in this region feeds the Tarim River and is required in the surrounding lowlands for agriculture and drinking water (Hagg et al., 2007). The prevailing climate can be described as continental and is characterized by low winter precipitation and convective rainfall events in summer (Aizen et al., 1997). The glacier reaches from 3060 to $6432 \mathrm{~m}$ a.s.l. with a length of $25 \mathrm{~km}$ and an area of $84 \mathrm{~km}^{2}$ (Han et al., 2010b). Debris thickness ranges from less than $0.01 \mathrm{~m}$ on the upper reach of the ablation area and on ice-cliff slopes to more than $3 \mathrm{~m}$ (Fig. 4) near the glacier terminus (Han et al., 2006; Wu and Liu, 2012). According to Yong et al. (2006) the glacier has an ablation zone of about $30.6 \mathrm{~km}^{2}$, with $60 \%$ of the area covered by debris. The equilibrium line altitude is $4300 \mathrm{~m}$ a.s.l. and the maximum glacier area is situated at the elevation band between 4600 and $4800 \mathrm{~m}$ a.s.l. (Han et al., 2010a).

\section{Data compilation}

\subsection{Ablation measurements}

From 10 August to 29 August 2010 a series of ablation measurements were performed on Koxkar Glacier. Ablation stakes were installed at locations with varying debris thicknesses and preferably horizontal surfaces. Ablation was also measured at several ice cliffs of different expositions and
Table 1. Ikonos satellite sensor specifications.

\begin{tabular}{lcccc}
\hline Satellite & Sensor & $\begin{array}{c}\text { Band } \\
\text { number }\end{array}$ & $\begin{array}{c}\text { Spectral } \\
\text { range }\end{array}$ & $\begin{array}{c}\text { Pixel } \\
\text { resolution }\end{array}$ \\
\hline \multirow{4}{*}{ Ikonos-2 } & Multi-spectral & $\begin{array}{c}1=\text { Blue } \\
2=\text { Green } \\
3=\text { Red } \\
4=\text { NIR }\end{array}$ & $\begin{array}{c}445-516 \mathrm{~nm} \\
506-595 \mathrm{~nm}\end{array}$ & $\begin{array}{c}632-698 \mathrm{~nm} \\
757-853 \mathrm{~nm}\end{array}$ \\
& & $\begin{array}{c}4 \mathrm{~m} \\
526-929 \mathrm{~nm}\end{array}$ & $1 \mathrm{~m}$ \\
\hline
\end{tabular}

on bare ice. To find out how the slope angles of the cliffs evolve, stakes have been placed orthogonal to the ice surface in the upper and the lower part of the ice cliffs. Debris cover thickness was measured at each stake during the installation process. Additionally, debris thickness along a longitudinal profile was measured in summer 2011 by scientists from the Cold and Arid Regions Environmental and Engineering Research Institute (CAREERI).

\subsection{Meteorological measurements}

Air temperature was measured by an automatic weather station (AWS) operated by CAREERI. The AWS is located near the glacier terminus at an elevation of $3009 \mathrm{~m}$ a.s.l. (Fig. 1). The respective air temperature sensor is an HMP45C, Campbell Scientific Inc., mounted $2 \mathrm{~m}$ above the ground surface. It is connected to a datalogger (CR1000, Campbell Scientific Inc.) which provides hourly records (Han et al., 2010a).

\subsection{Remote sensing}

High-resolution images from the Ikonos satellite have been used to generate a digital elevation model (DEM) from the entire Koxkar Glacier catchment. Ikonos provides panchromatic images with $1 \mathrm{~m}$ resolution and multispectral imagery with $4 \mathrm{~m}$ resolution (Table 1). A cloud-free Ikonos image was acquired on 30 April 2009, 13:32 LT. The solar elevation was $60.1^{\circ}$ and the solar azimuth was $149.6^{\circ}$.

An ASTER (Advanced Spaceborne Thermal Emission and Reflection Radiometer) Level 1B granule was processed to obtain land surface temperature (LST) following the approach by $\mathrm{Pu}$ et al. (2006). The observation date is 10 April 2007, the local observation time is 13:39 and the spatial resolution of the thermal infrared channel, which is used to obtain LST, is $90 \mathrm{~m}$. The ASTER scene was selected because no snow or clouds are present over the debris covered area in the acquired image. Ikonos and ASTER images were co-registered.

\section{Methods}

\subsection{Ablation model design}

To compare ablation rates of several locations and time spans, mean degree day factors were calculated using the 

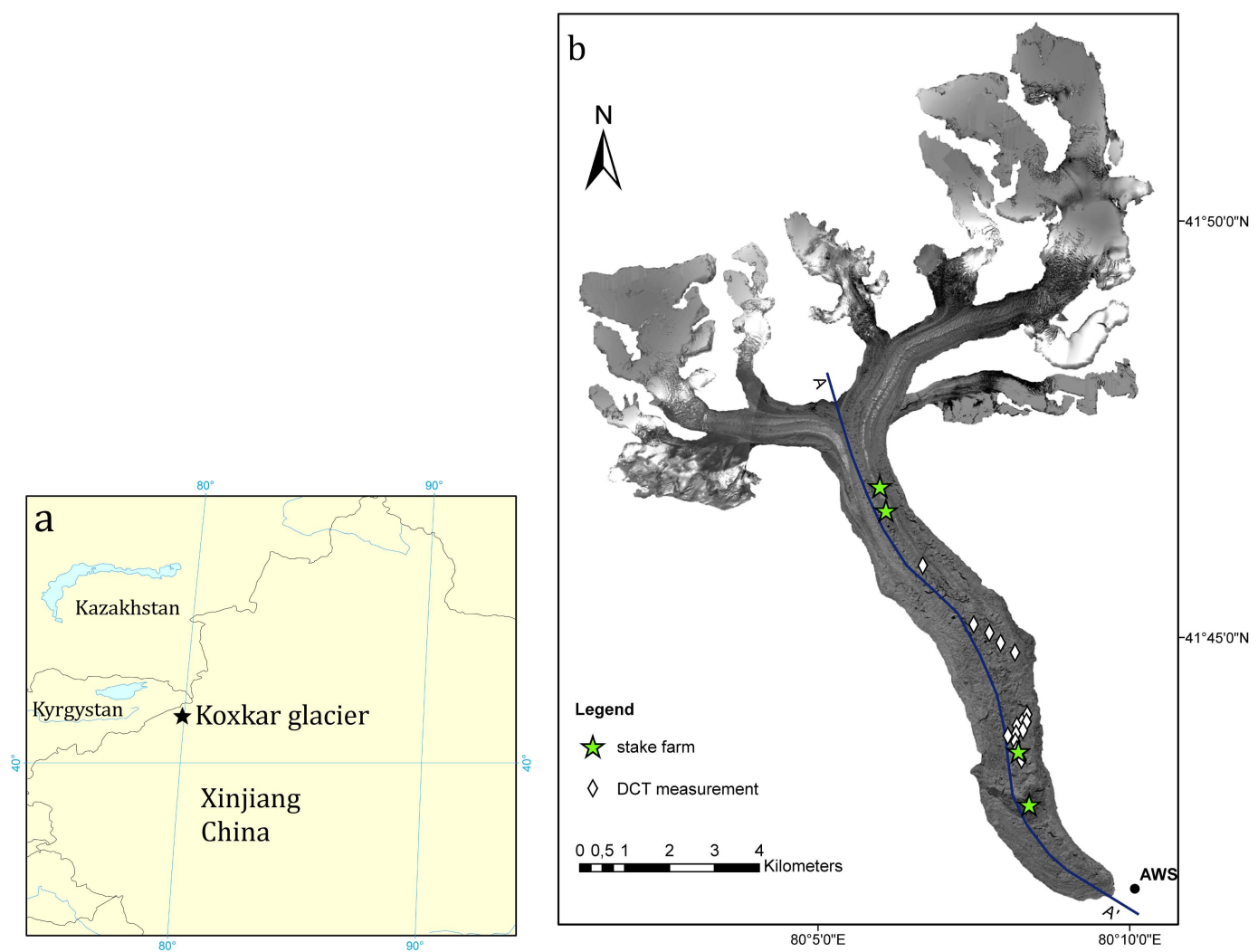

Fig. 1. (a) The location of Koxkar Glacier in western China. (b) An orthoimage of the debris covered glacier, including the position of the AWS and the profile $\mathrm{A}-\mathrm{A}^{\prime}$.

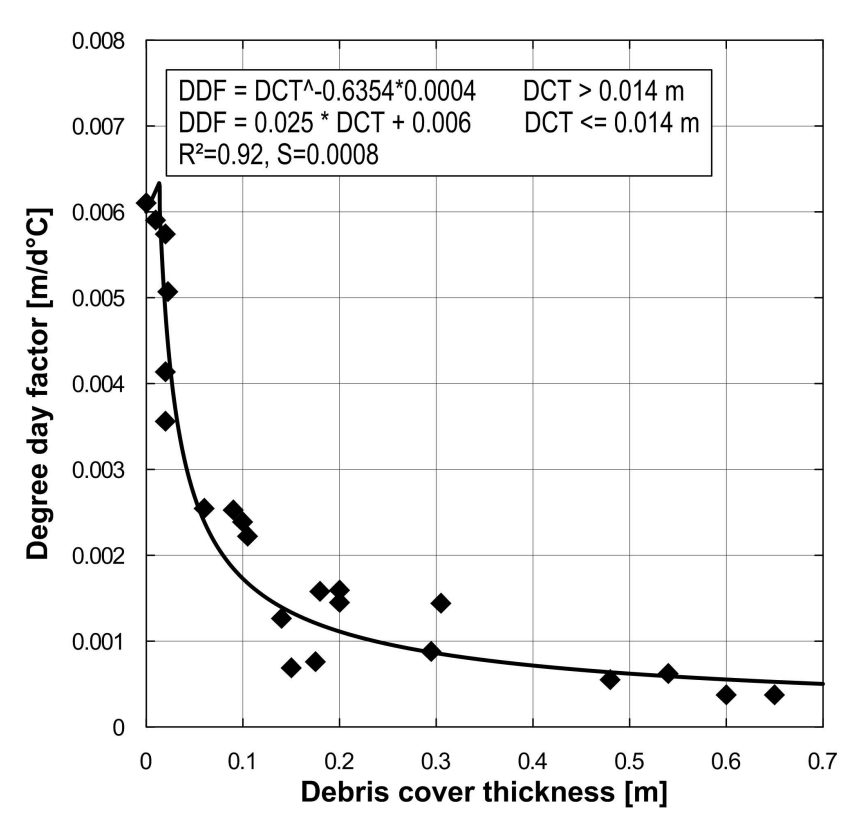

Fig. 2. Degree day factors of individual stakes plotted against debris cover thickness. The black line represents the empirical equations used in the ablation model. $R^{2}$ is the coefficient of determination and $S$ is the standard error of the regression. measured melt and the sum of positive degree days for the bare ice stake and the debris covered ice stakes (Braithwaite, 1995). Daily ablation is then expressed in the degree day factor times the difference between daily mean temperature and a threshold temperature that was set to $0^{\circ} \mathrm{C}$. The temperature data was extrapolated to higher elevations using a (lapse rate) of $-0.008^{\circ} \mathrm{C} \mathrm{km}^{-1}$ (from 3000 to $3700 \mathrm{ma.s.1}$.) and $-0.004^{\circ} \mathrm{Ckm}^{-1}$ (from $3700 \mathrm{~m}$ a.s.l. and above) respectively. These lapse rates have been determined for the ablation season (May to September) by Han et al. (2008) on the basis of measured air temperature at two different AWS located on the glacier (observation in 2003 and 2004) and the AWS in the vicinity of the glacier described above (long-term observation). Han et al. (2008) state that the drastic change in temperature lapse rate at an elevation of $3700 \mathrm{~m}$ a.s.1. is because of the transition from a broad supraglacial debris cover in the lower parts to a debris free ice surface in the middle and upper parts of the glacier. Ablation rates and their relation to debris thickness are determined empirically. To obtain an equation that represents the connection from debris cover thickness to degree day factor, measured ablation, debris thickness and extrapolated temperatures are taken into account (Hagg et al., 2008). 

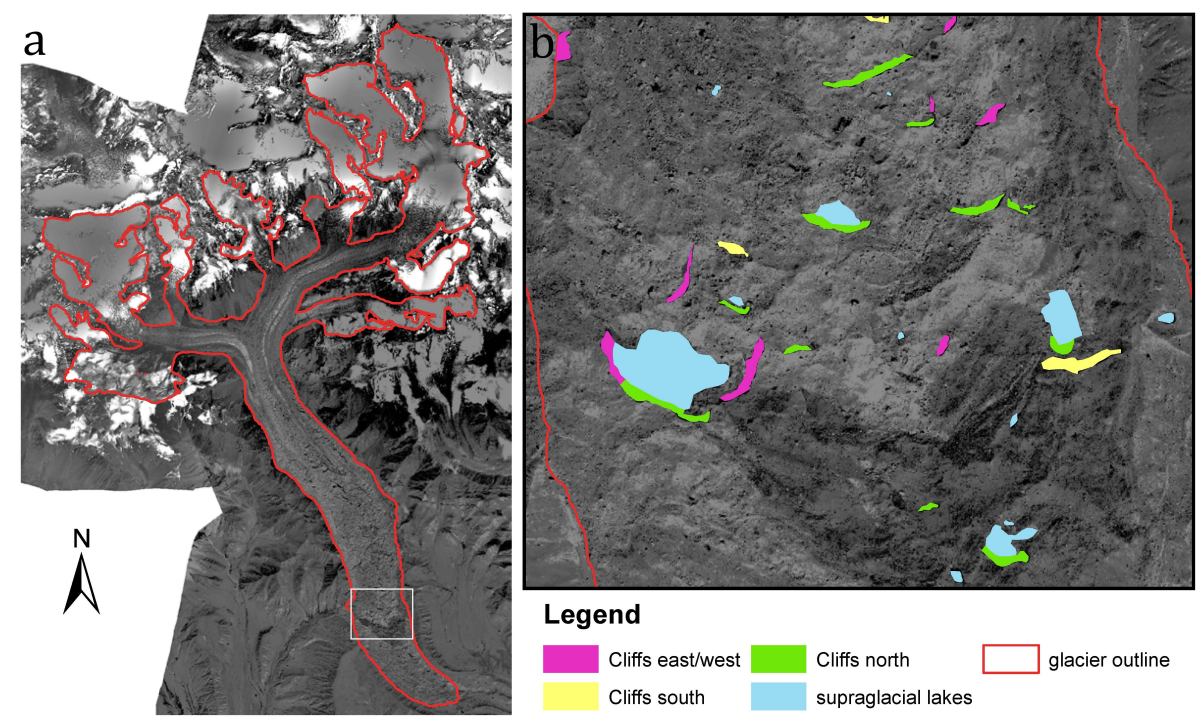

Fig. 3. (a) Overview of the study area with glacier outlines. (b) Detail of the glacier tongue. Ice cliffs and supraglacial lakes have been mapped manually (source: orthorectified Ikonos image).

Different curve fittings were tested, but a power law regression provides the most reliable equation because of the asymptotic approximation to the $x$ axis. To take account of the fact that the degree day factor for very thin layers of debris cover is enhanced compared to bare ice, a linear equation is used for debris thicknesses smaller than $0.014 \mathrm{~m}$, where the power law regression would produce unrealistically high degree day factors. Considering the simplicity of the equation, there is good agreement between the measurements and the regression equation with a coefficient of determination of 0.92 (Fig. 2).

On 12 ice cliffs ablation was measured perpendicular to the surface. Mean degree day factors for north facing $\left(0.0043 \mathrm{md}^{-1}{ }^{\circ} \mathrm{C}^{-1}\right)$, south facing $\left(0.0054 \mathrm{md}^{-1}{ }^{\circ} \mathrm{C}^{-1}\right)$ and east/west facing cliffs $\left(0.0052 \mathrm{md}^{-1}{ }^{\circ} \mathrm{C}^{-1}\right)$ were calculated and applied within the model. For supraglacial lakes the melt rates at the lake bottom are estimated using the same degree day factor - debris cover thickness regression, but instead of calculating the sum of positive degree days based on the air temperature record, the overlying water is assumed to have a constant temperature of $4^{\circ} \mathrm{C}$ for the period from 1 May 2010 to 31 October 2010. This assumption is supported by the work of Xin et al. (2012), who monitored the thermal regime of a supraglacial lake during ablation season at Koxkar Glacier in 2008. One drawback of the present model is that the lateral melting below the water surface in the ponds is not included, because the dynamic evolution of the debris mantle is not incorporated. Taking into consideration that lakes occupy only $0.36 \%$ of the glacier area, the error arising from this is rather small for one ablation season.

The mapping and area calculations of supraglacial lakes and steep ice cliffs were carried out with the stereo image data provided by the Ikonos product (Fig. 3). For this pur-

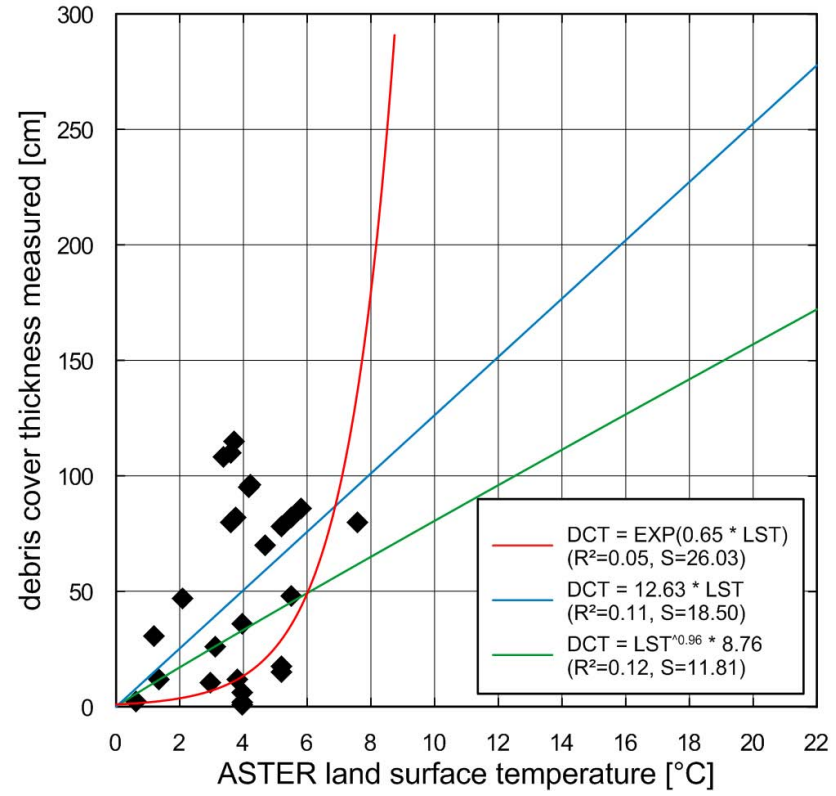

Fig. 4. Debris cover thickness (DCT) vs. ASTER LST with three different regression methods. $R^{2}$ is the coefficient of determination and $S$ is the standard error of the regression.

pose a digital elevation model (DEM) with a spatial resolution of $6 \mathrm{~m}$ was generated utilizing stereo satellite image data. The orthorectified multispectral images in combination with the derived elevation model were used to detect surfaces like ice, water or ice cliffs semi-automatically. Because the ice cliff area is measured in the horizontal projection from an orthophoto, the actual area of the cliffs was determined using a standard slope angle of $45^{\circ}$ according to Han et al. (2010b), 

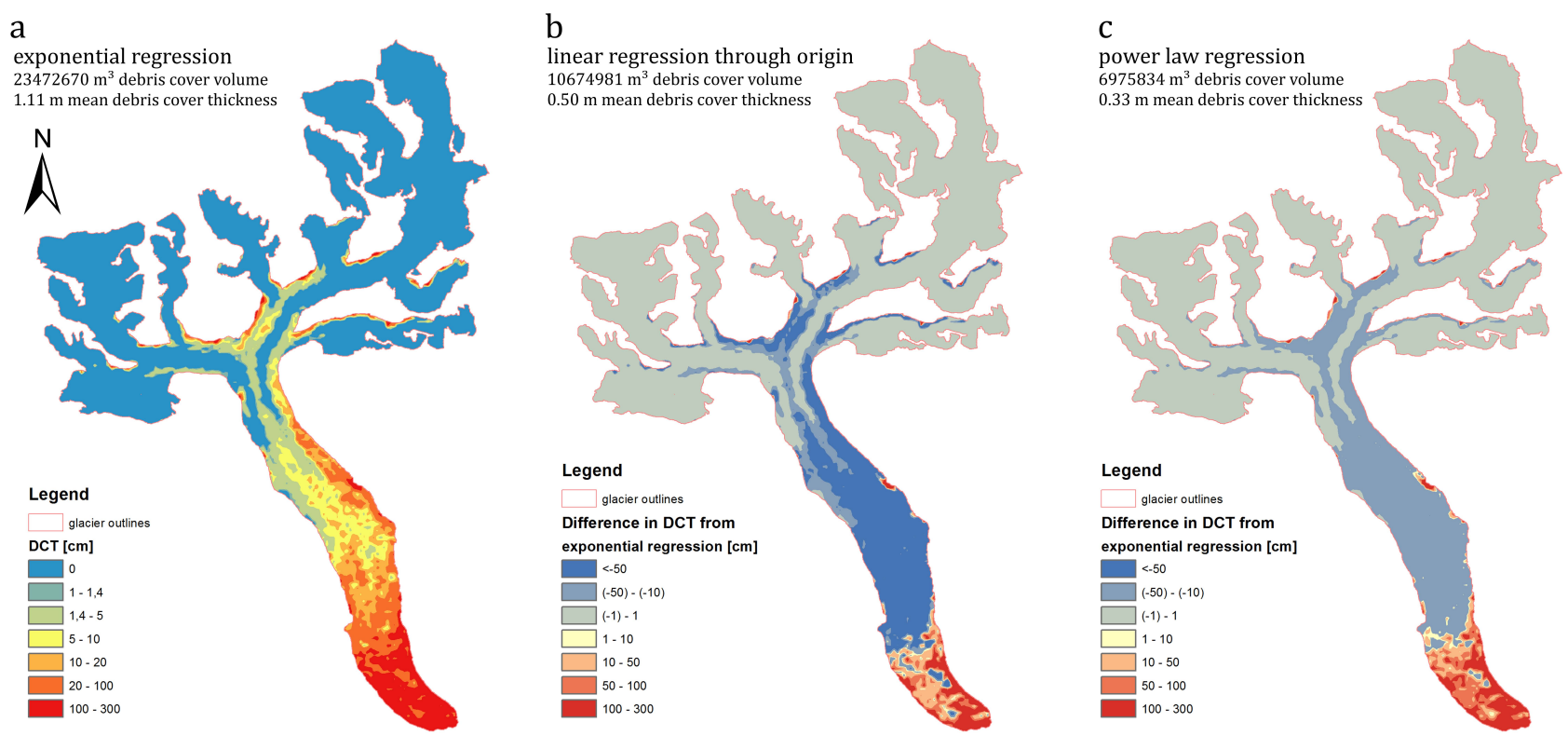

Fig. 5. (a) Debris cover thickness distribution derived from LST for the exponential regression (coefficients as in Fig. 4). (b) Difference in DCT for the linear regression through the origin relative to the exponential regression. (c) Difference in DCT for the power law regression relative to the exponential regression.

which represents a reasonable mean value for the observed cliff slopes. During the observation period in the ablation season 2010 no change in inclination was determined. The slope angle of the observed cliffs was in between $40^{\circ}$ and $50^{\circ}$ and fits well with the determined mean value. In the case of the ice cliffs a combination of the slope, derived from the DEM, and a greyscale filter applied to the panchromatic image, yields the best result. Unfortunately a large number of ice cliffs are not recognized by this approach because of their small size. The method is limited to features that are larger than the pixel size of the DEM derived from IKONOS data. Therefore these features were picked manually with the aid of the semi-automatic method.

For the lake detection the normalized difference water index (NDWI) developed by Huggel et al. (2002) was used. Two spectral channels with maximum reflectance difference for water (blue and near-infrared channels) were utilized.

To estimate debris cover thickness from thermal satellite imagery an empirical approach was used. Mihalcea et al. (2008) showed the strong correlation between ASTERderived LST and debris thickness. To obtain a map of debris thickness distribution we investigated the relation between those two parameters (Fig. 4). Unfortunately, our data did not reveal a significant correlation. To find out how sensitively the model responds to different debris patterns the three different regressions ((a) an exponential regression (b) a linear regression through the origin and (c) a power law regression) shown in Fig. 4 were tested. The ASTER image was resampled to a pixel size of $10 \mathrm{~m} \times 10 \mathrm{~m}$ so that the ablation model is able to resolve small features like ice cliffs.
The resulting debris cover thickness distribution maps are shown in Fig. 5. The exponential regression leads to very thick debris covers for high temperatures, but when compared to debris cover thickness from Wu and Liu (2012) (Fig. 6) it seems to be the most realistic and therefore is used as the default choice in the following figures. The debris cover thickness at the bottom of the lakes was also taken from this map. The patterns of the three debris cover thickness distributions are very similar, although the resulting thicknesses differ, especially in the tongue area where the highest values can be found.

The total debris cover volume can now be calculated by accumulating the pixel values of the entire debris covered area of the corresponding map (Fig. 5).

\section{Results and discussion}

\subsection{Areal distribution of features}

The areal distribution of the features that are relevant for the ablation model are summarized in Table 2. The statistic shows that more than $32 \%$ of the entire glacierized area is covered with debris. The areas of ice cliffs occupy $1.70 \%$, the area of the supraglacial lakes $0.36 \%$ of the debris covered area. 


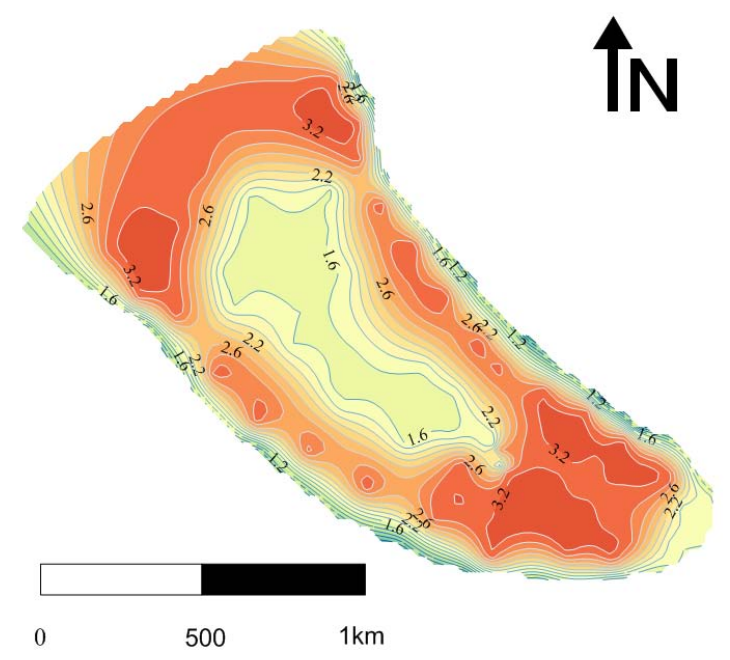

Fig. 6. Distribution of debris cover thickness on the terminus of Koxkar Glacier derived from multi-frequency ground penetrating radar. Redrawn from Wu and Liu (2012).

\subsection{Role of the spatial distribution of debris thickness patterns}

In Fig. 7 the modelled ice ablation for the time span of 1 May 2010 to 31 October 2010 is shown. This period covers the entire ablation season; before and after this time period no temperatures above $0{ }^{\circ} \mathrm{C}$ were measured at the AWS.

The comparison of total ice melt of the different debris thickness regressions is shown in Fig. 8.

The bare ice ablation and the ice cliff ablation are the same for all of the three regressions due to the model structure. The features are all in the same location and their degree day factors are constant. Therefore the only difference in total ice ablation arises from debris cover thickness that has an effect on the sub-debris ice ablation. The sub-debris ice ablation accounts for $33 \%$ in the case of the exponential regression, for $17 \%$ in the case of the linear regression and for $21 \%$ in the case of the power law regression of the entire ice ablation. Although the ice cliffs are relatively small in area $(1.7 \%$ of the debris covered area) the melt amount accounts for 7-16\% of the total sub-debris ablation and 2-3\% of the total ablation respectively (Table 3 ).

These results are not in line with the findings of Sakai et al. (1998), who state that the ice cliff melt amount reaches $69 \%$ of the total ablation at the debris covered area, although the area of ice cliffs occupies less than $2 \%$ of the debris covered area on Lirung Glacier in Nepal. Despite the analogy in the fraction of ice cliffs of the debris covered area, the ice cliff melt amount differs significantly. The discrepancy could be explained by the fact that Sakai et al. (1998) used an average melt rate for the entire debris covered area and therefore did not account for the spatial distribution of debris thickness. However, variations may also arise due to climatic differences between the sites and the fact that many of the ice
Table 2. Horizontally projected area of the melt-relevant surface types on Koxkar Glacier derived from satellite imagery mapping.

\begin{tabular}{lc}
\hline & Feature area \\
\hline Entire glacierized area & $65.60 \mathrm{~km}^{2}$ \\
Debris covered area & $21.17 \mathrm{~km}^{2}$ \\
Cliffs & $0.36 \mathrm{~km}^{2}$ \\
Supraglacial lakes & $0.08 \mathrm{~km}^{2}$ \\
\hline
\end{tabular}

cliffs on Lirung Glacier are beside supraglacial ponds, where cliff retreat rates are higher.

\subsection{Influence of debris cover on the response of the glacier terminus}

It is stated by several authors that debris covered glaciers respond differently to climate change than bare ice glaciers (Bolch et al., 2008; Sorg et al., 2012; Scherler et al., 2011). During years of negative mass balance the position of the terminus region remains stable while the debris covered parts react by surface lowering. This downwasting behaviour is also reported for Koxkar Glacier (Pieczonka et al., 2013). The significant difference in the terminus evolution is related to the facts that debris cover is present and the decreasing ice flow velocity due to reduction of ice thickness and surface gradient (Benn et al., 2012). The ablation model allows us to compare melt rates of the debris covered Koxkar Glacier with the ablation if no debris were present on the glacier surface. Figure 9 shows the direct comparison of melt rates including a zoomed section of the glacier terminus. It becomes quite clear why debris covered glaciers respond differently in a particular climate setting. While the melt amount on the bare ice glacier reaches values of approximately $8 \mathrm{~m}$ in one ablation season, the ablation on the debris covered glacier almost comes to a standstill. The ice cliffs are the exception and can easily be spotted as melt hotspots with values up to $8.5 \mathrm{~m}$ melt on the debris covered tongue. For the supraglacial lake grounds a slightly inferior ablation can be observed when compared with the surrounding subdebris melt. Another important point is the melt gradient: the modelled ablation on the bare ice tongue exhibits the temperature and elevation dependence of the melt rates. In the case of the debris covered glacier this effect is not present. Due to the fact that the curve in Fig. 2 levels out beyond $0.1 \mathrm{~m}$, no significant changes in ablation are observable along the lower tongue profile (Fig. 10). At lower elevations, the increasing debris thickness compensates for the higher temperature.

In Fig. 10 the longitudinal section $\mathrm{A}-\mathrm{A}^{\prime}$ (Fig. 1) of the tongue of Koxkar Glacier is presented. The DEM is shown as a solid green line, and the ablations of the bare ice glacier and the debris covered glacier are displayed as a red line and black line respectively. In the higher parts, where debris cover thickness is rather small, the differences are not as 

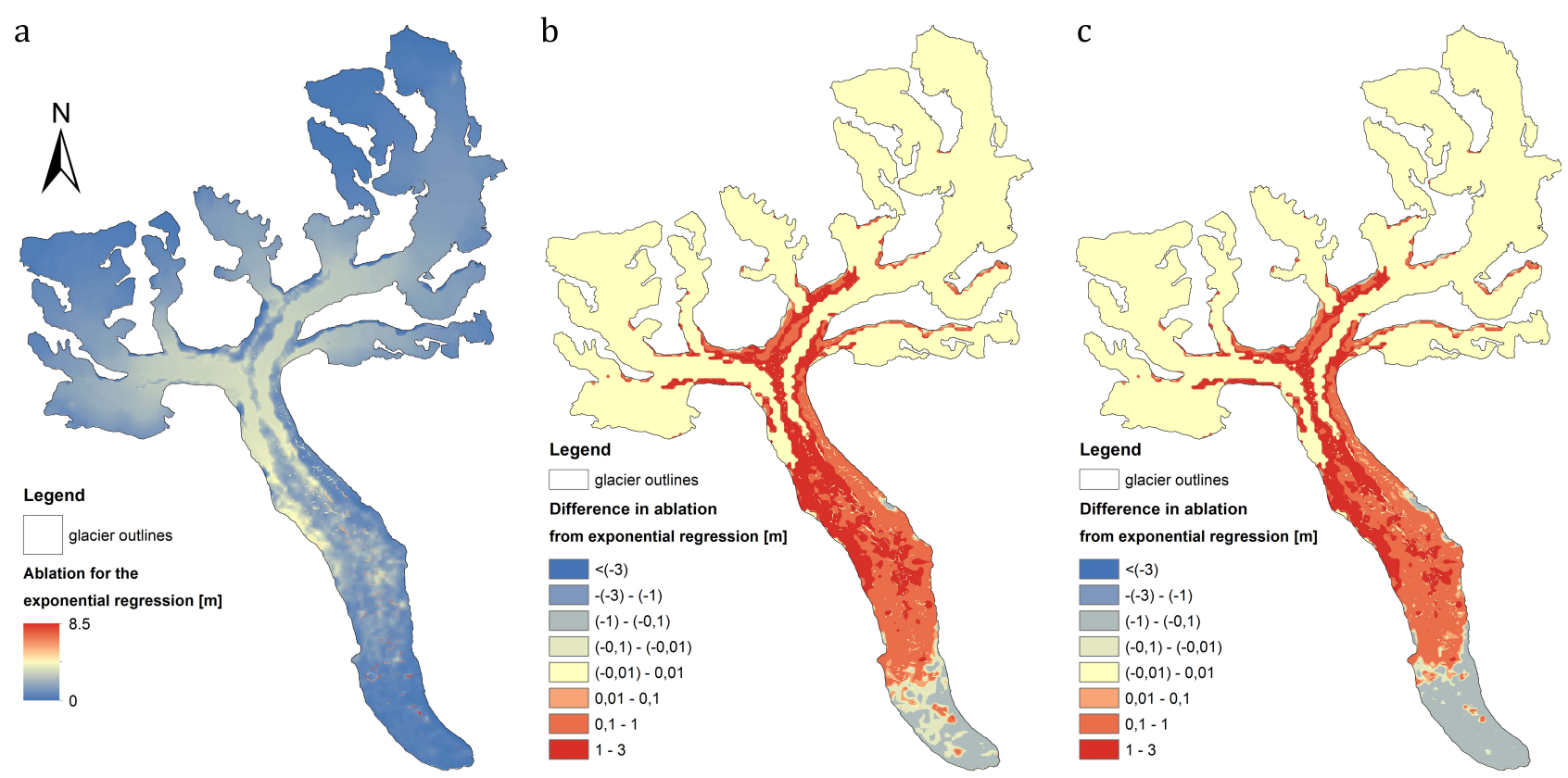

Fig. 7. (a) Distribution of calculated total ice ablation for the exponential regression during the time span of 1 May 2010 to 31 October 2010. (b) Difference in ablation for the linear regression through the origin relative to the exponential regression. (c) Difference in ablation for the power law regression relative to the exponential regression.

Table 3. Percentage of ice cliff melt of total ablation and sub-debris ablation respectively.

\begin{tabular}{llcc}
\hline & $\begin{array}{l}\text { Exponential } \\
\text { regression }\end{array}$ & $\begin{array}{c}\text { Linear regression } \\
\text { through the origin }\end{array}$ & $\begin{array}{c}\text { Power law } \\
\text { regression }\end{array}$ \\
\hline $\begin{array}{l}\text { Ice cliff ablation } \\
\text { of the total ablation }\end{array}$ & $2.19 \%$ & $2.71 \%$ & $2.59 \%$ \\
$\begin{array}{l}\text { Ice cliff ablation of the } \\
\text { total sub debris ice ablation }\end{array}$ & $6.57 \%$ & $15.62 \%$ & $12.35 \%$ \\
\hline
\end{tabular}

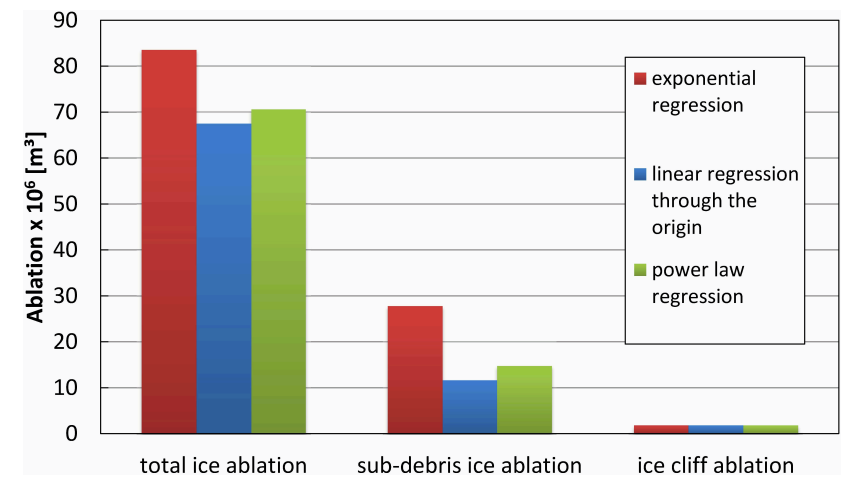

Fig. 8. Sum of ablation for the time span of 1 May 2010 to 31 October 2010 for different debris cover thickness regressions. manifest as in the lower parts, where subdebris ablation almost ceases. Figure 10 also exhibits the influence of the ice cliffs, where the ablation reaches values beyond the bare ice case.

The substantial differences between a debris covered and a debris free glacier become evident when looking at the total ablation amount. Whereas for the debris covered glacier the total ice ablation is in the range of $68-84 \times 10^{6} \mathrm{~m}^{3}$ $\left(84 \times 10^{6} \mathrm{~m}^{3}\right.$ for the exponential regression, $68 \times 10^{6} \mathrm{~m}^{3}$ for the linear regression through the origin and $71 \times 10^{6} \mathrm{~m}^{3}$ for the power law regression), the ice melt at the debris free glacier would be $150 \times 10^{6} \mathrm{~m}^{3}$. Thus, it becomes clear how important the consideration of debris cover in predictions of future melt water availability really is. Our presented results do not support the statement of Kääb et al. (2012) that the insulating effect of debris layers with thicknesses exceeding a critical thickness acts on local scales of intact covers, but not in general on the spatial scale of entire glacier tongues. 
a

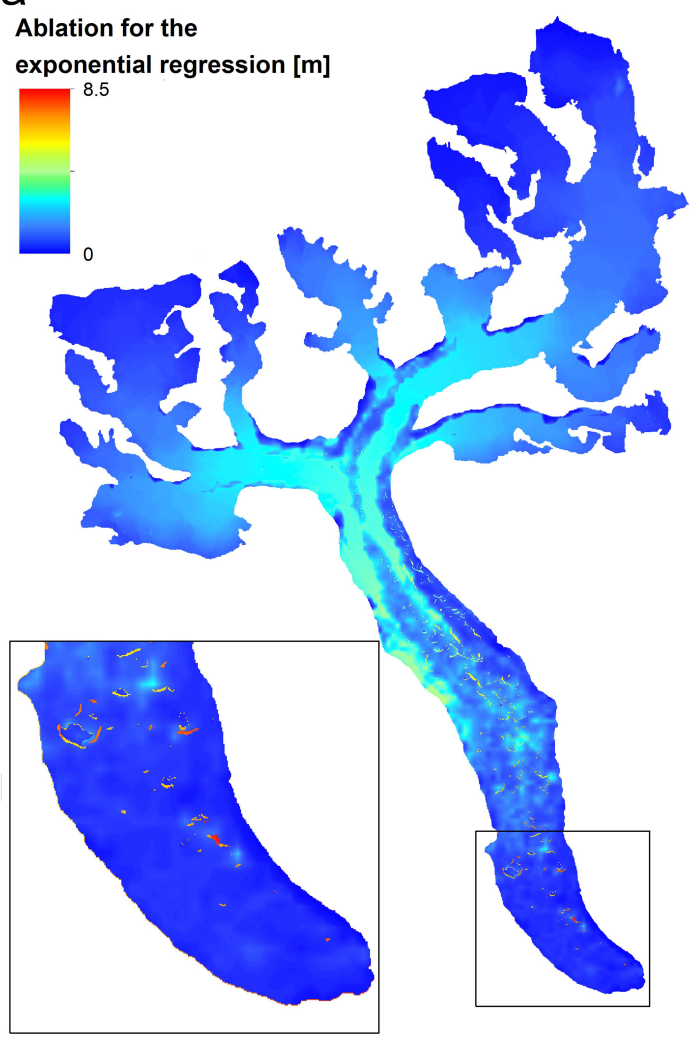

b

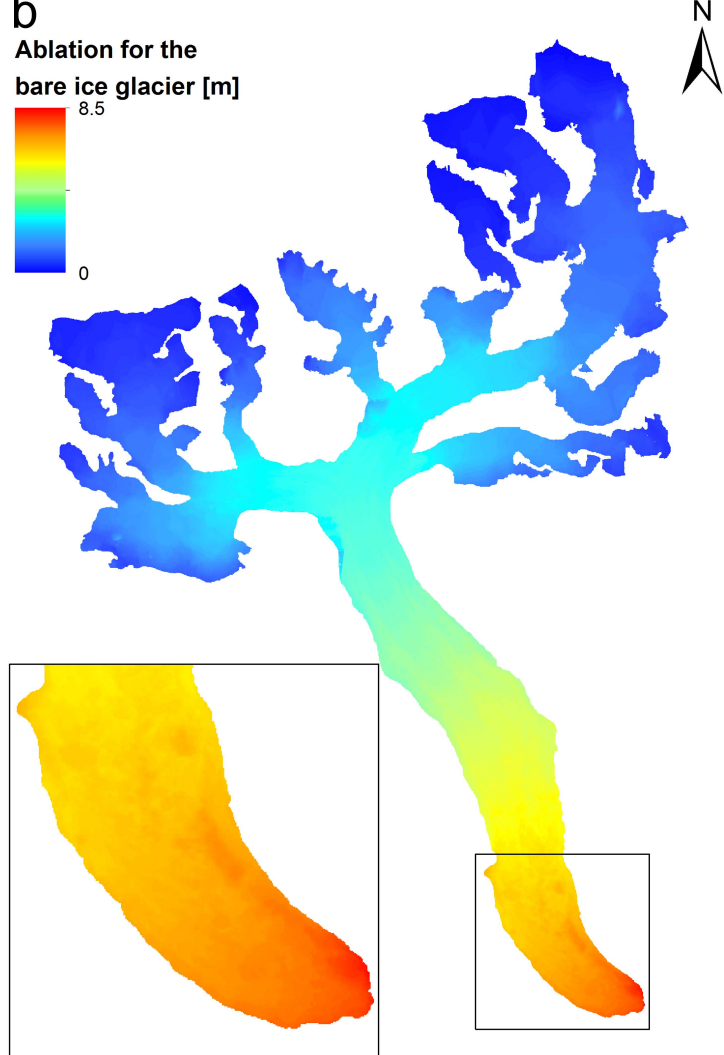

Fig. 9. Distribution of ice ablation for the time span of 1 May 2010 to 31 October 2010, including a zoomed section of the terminus. (a) Debris covered Koxkar Glacier using the exponential regression; (b) ablation if no debris were present on the glacier surface.

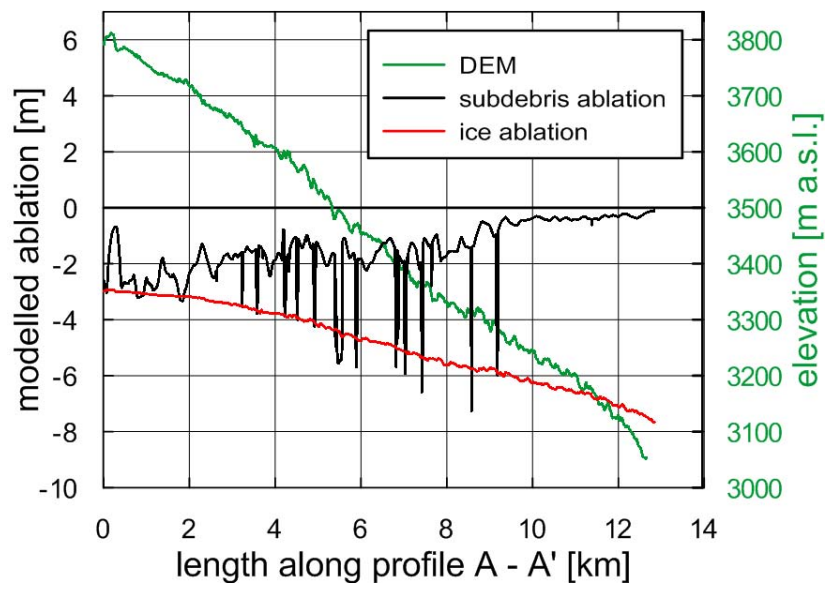

Fig. 10. DEM (green line), ice ablation (red line) and subdebris ablation (black line) along the profile A-A' (Fig. 1) for the exponential regression of debris cover thickness.

\section{Conclusions and outlook}

The exponential regression of debris cover thickness appears to be the most realistic when compared to the multifrequency ground penetrating radar measurements from $\mathrm{Wu}$ and Liu (2012), who have been able to derive a map of debris cover thickness in the lowest part of the glacier terminus (Fig. 6).

The results regarding ablation indicate that melt on ice cliffs plays a significant role but not as substantial as stated by Sakai et al. (1998).

Our study highlights the influence of debris cover on the response of the glacier terminus in a particular climate setting. Due to the fact that melt rates are highly restricted, the shielding effect of the debris cover dominates over the temperature and elevation dependence of the ablation in the bare ice case. In addition, the reduced melt rates highlight the serious implications with regard to runoff modelling from debris covered glaciers. The comparison of total ablation amount from a debris free and a debris covered glacier underlines the importance of including debris cover in discharge modelling.

The representation of debris covered glacier parts in hydrological models is still an unsolved problem. By implementing the presented ablation model in a conceptual runoff 
model, an improved version of the HBV-ETH model (Mayr et al., in preparation) capable of reproducing runoff from debris covered glaciers will be created. Moreover, runoff scenarios for changing climate and glaciation conditions can be realised after the calibration of the model has been completed for current conditions. Results from regional and local climate modelling will serve as input for the improved HBVETH model version, allowing the model to run with the output of sophisticated climate modelling.

Acknowledgements. The authors would like to thank E. Mayr and L. Qiao for assisting with the fieldwork. The funding of the study by the Deutsche Forschungsgemeinschaft (MA 3347/4-1) in the context of the AKSU-TARIM project bundle (Water Resources in Western China) is gratefully acknowledged.

Edited by: M. van den Broeke

\section{References}

Aizen, V. B., Aizen, E. M., Melack, J. M., and Dozier, J.: Climatic and Hydrologic Changes in the Tien Shan, Central Asia, J. Climate, 10, 1393-1404, 1997.

Benn, D. I., Bolch, T., Hands, K., Gulley, J., Luckman, A., Nicholson, L. I., Quincey, D., Thompson, S., Toumi, R., and Wiseman, S.: Response of debris-covered glaciers in the Mount Everest region to recent warming, and implications for outburst flood hazards, Earth-Sci. Rev., 114, 156-174, 2012.

Bolch, T., Buchroithner, M. F., Peters, J., Baessler, M., and Bajracharya, S.: Identification of glacier motion and potentially dangerous glacial lakes in the Mt. Everest region/Nepal using spaceborne imagery, Nat. Hazards Earth Syst. Sci., 8, 13291340, doi:10.5194/nhess-8-1329-2008, 2008.

Bolch, T., Kulkarni, A., Kääb, A., Huggel, C., Paul, F., Cogley, J. G., Frey, H., Kargel, J. S., Fujita, K., Scheel, M., Bajracharya, S., and Stoffel, M.: The State and Fate of Himalayan Glaciers, Science, 336, 310-314, 2012.

Braithwaite, R. J.: Positive degree-day factors for ablation on the Greenland ice sheet studied by energy-balance modelling, J. Glaciol., 41, 153-159, 1995.

Braun, L. N., Weber, M., and Schulz, M.: Consequences of climate change for runoff from Alpine regions, Ann. Glaciol., 31, 19-25, 2000.

Gulley, J. and Benn, D.: Structural control of englacial drainage systems in Himalayan debris-covered glaciers, J. Glaciol., 53, 399412, 2007.

Hagg, W., Braun, L., Kuhn, M., and Nesgaard, T.: Modelling of hydrological response to climate change in glacierized Central Asian catchments, J. Hydrol., 332, 40-53, 2007.

Hagg, W., Mayer, C., Lambrecht, A., and Helm, A.: Sub-debris melt rates on southern Inylchek glacier, Central Tian Shan, Geogr. Ann. A, 90, 55-63, 2008.

Han, H., Ding, Y., and Liu, S.: A simple model to estimate ice ablation under a thick debris layer, J. Glaciol., 52, 528-536, 2006.

Han, H., Liu, S., Ding, Y., Deng, X., Wang, Q., Xie, C., Wang, J., Zhang, Y., Li, J., Shangguan, D., Zhang, P., Zhao, J., Niu, L., and Chen, C.: Near-Surface Meteorological Characteristics on the Koxkar Baxi Glacier, Tianshan, J. Glaciology and Geocryology, 30, 967-975, 2008.

Han, H., Liu, S., Wang, J., Wang, Q., and Xie, C.: Glacial runoff characteristics of the Koxkar Glacier, Tuomuer-Khan Tengri Mountain Ranges, China, Environmental Earth Sciences, 61, 665-674, 2010a.

Han, H., Wang, J., Wei, J., and Liu, S.: Backwasting rate on debriscovered Koxkar glacier, Tuomuer mountain, China, J. Glaciol., 56, 287-296, 2010b.

Huggel, C., Kääb, A., Haeberli, W., Teysseire, P., and Paul, F.: Remote sensing based assessment of hazards from glacier lake outbursts: a case study in the Swiss Alps, Can. Geotech. J., 39, 316330, 2002.

Kääb, A., Berthier, E., Nuth, C., Gardelle, J., and Arnaud, Y.: Contrasting patterns of early twenty-first-century glacier mass change in the Himalayas, Nature, 488, 495-498, doi:10.1038/nature11324, 2012.

Mayr, E., Juen, M., Mayer, C., and Hagg, W.: Modelling runoff from Inylchek glacier and filling of ice-dammed Lake Merzbacher, Central Tian Shan, in preparation, 2014.

Mihalcea, C., Brock, B., Diolaiuti, G., D’Agata, C., Citterio, M., Kirkbride, M., Cutler, M., and Smiraglia, C.: Using ASTER satellite and ground-based surface temperature measurements to derive supraglacial debris cover and thickness patterns on Miage Glacier (Mont Blanc Massif, Italy), Cold Reg. Sci. Technol., 52, 341-354, 2008.

Nicholson, L. and Benn, D. I.: Calculating ice melt beneath a debris layer using meteorological data, J. Glaciol., 52, 463-470, 2006.

Østrem, G.: Ice Melting under a Thin Layer of Moraine, and the Existence of Ice Cores in Moraine Ridges, Geogr. Ann., 41, 228230, 1959.

Pieczonka, T., Bolch, T., Junfeng, W., and Shiyin, L.: Heterogeneous mass loss of glaciers in the Aksu-Tarim Catchment (Central Tien Shan) revealed by 1976 KH-9 Hexagon and 2009 SPOT5 stereo imagery, Remote Sens. Environ., 130, 233-244, 2013.

Pu, R., Gong, P., Michishita, R., and Sasagawa, T.: Assessment of multi-resolution and multi-sensor data for urban surface temperature retrieval, Remote Sens. Environ., 104, 211-225, 2006.

Reid, T. D. and Brock, B. W.: An energy-balance model for debriscovered glaciers including heat conduction through the debris layer, J. Glaciol., 56, 903-916, 2010.

Sakai, A., Nakawo, M., and Fujita, K.: Melt rate of ice cliffs on the Lirung Glacier, Nepal Himalayas, 1996, Bulletin of Glacier Research, 16, 57-66, 1998.

Sakai, A., Takeuchi, N., Fujita, K., and Nakawo, M.: Role of supraglacial ponds in the ablation process of a debris-covered glacier in the Nepal Himalayas, in: Debris covered Glaciers, IAHS Publications No. 265, 119-132, 2000.

Sakai, A., Nakawo, M., and Fujita, K.: Distribution characteristics and energy balance of ice cliffs on debris-covered glaciers, Nepal Himalaya, Arct. Antarct. Alp. Res., 34, 12-19, 2002.

Scherler, D., Bookhagen, B., and Strecker, M. R.: Spatially variable response of Himalayan glaciers to climate change affected by debris cover, Nat. Geosci., 4, 156-159, 2011.

Schomacker, A.: What controls dead-ice melting under different climate conditions? A discussion, Earth-Sci. Rev., 90, 103-113, 2008. 
Sorg, A., Bolch, T., Stoffel, M., Solomina, O., and Beniston, M.: Climate change impacts on glaciers and runoff in Tien Shan (Central Asia), Nat. Clim. Change, 2, 725-731, 2012.

$\mathrm{Wu}, \mathrm{Z}$. and Liu, S.: Imaging the debris internal structure and estimating the effect of debris layer on ablation of Glacier ice, J. Geol. Soc. India, 80, 825-835, 2012.

Xin, W., Shiyin, L., Haidong, H., Jian, W., and Qiao, L.: Thermal regime of a supraglacial lake on the debris-covered Koxkar Glacier, southwest Tianshan, China, Environmental Earth Sciences, 67, 175-183, 2012.
Yong, Z., Shi-yin, L., Yong-jian, D., Jing, L., and Donghui, S.: Preliminary Study of Mass Balance on the Keqicar Baxi Glacier on the South Slopes of Tianshan Mountains, Journal of Glaciology and Geocryology, 28, 477-484, 2006. 